\title{
Pemberdayaan Siswa Berkebutuhan Khusus dalam Mengakses Open Access System Guna Meningkatkan Capability Learner
}

\author{
Rizqi Fajar Pradipta*, Ence Surahman, Umi Saiful Ummah \\ rizqi.fajar.fip@um.ac.id \\ Teknologi Pendidikan, Fakultas IImu Pendidikan, Universitas Negeri Malang \\ Diterima10 September 2019, dipublikasikan 31 Oktober 2019
}

\begin{abstract}
Abstrak
Kegiatan pengabdian pada masyarakat ini merupakan upaya kegiatan pengabdian masyarakat yang dilakukan dalam bentuk pelatihan bagi siswa-siswa berkebutuhan khusus di Sekolah Luar Biasa Putra Mandiri Kabupaten Sidoarjo. Adapun metode yang digunakan dalam pelatihan meliputi; 1) Ceramah dan Tanya jawab untuk menyampaikan wawasan dunia kerja dan tentang persiapan masuk dalam dunia kerja sebagai sarana membentuk etos kerja atau mental kerja dalam dunia kerja; 2) Praktek; 3)Diskusi untuk melakukan evaluasi rekomendasi pada seluruh peserta Pemberdayaan. Pada akhir kegiatan pemberdayaan ini diharapkan siswa berkebutuhan khusus di Sekolah Luar Biasa Putra Mandiri Kabupaten Sidoarjo memiliki peningkatan kapabilitas yang nantinya dapat terwujud menjadi figur siswa berkebutuhan khusus yang mandiri dan memiliki kecapakan hidup yang baik.
\end{abstract}

Kata kunci: Pemberdayaan, Siswa Berkebutuhan Khusus, Open Access System

\section{PENDAHULUAN}

Pada saat ini semakin gencar di seluruh penjuru dunia untuk menggaungkan peradaban yang telah masuk kedalam revolusi industri 4.0, dimana seluruh kegiatan atau aktifitas manusia akan terhubung dalam jaringan (Online). Hal itu ditandai dengan kegiatan atau aktifitas tanpa perlu adanya sebuah mobilitas manusia sudah bisa terhubung dengan manusia lainnya, bahkan hingga manusia dalam memenuhi seluruh kebutuhannya hanya cukup memainkan jari jemari melalui media smartphone atau gadget lainnya, asal mereka memiliki jaringan internet (Prasetyo \& Sutopo, 2018; Suwardana, 2018; Tjandrawinata, 2016). Imbas dari revolusi ini juga berdampak pada sekeliling manusia itu sendiri. Seperti halnya pekerjaan dan pendidikan yang telah berkembang seiring kemajuan teknologi saat ini. Perkembangan tersebut mengharuskan manusia bukan lagi memerlukan sebuah kompetensi melainkan sebuah kapabilitas. Kapabilitas memiliki definisi seperti dalam (Untara, 2014) adalah Kapabilitas, artinya juga sama dengan Kompetensi, yaitu Kemampuan. Namun pemaknaan kapabilitas tidak sebatas memiliki keterampilan (skill) saja namun lebih dari itu, yaitu lebih paham secara mendetail sehingga benar benar menguasai kemampuannya dari titik kelemahan hingga cara mengatasinya (definisi kapabilitas dan teori terkait kapabilitas). Pengertian kapabilitas menurut (Baker \& Sinkula, 2005) kapabilitas adalah kumpulan keterampilan yang lebih spesifik, prosedur, dan proses yang dapat memanfaatkan sumber daya ke keunggulan kompetitif.

\begin{tabular}{llccccccccc}
\hline \multirow{2}{*}{ No } & \multirow{2}{*}{ Wilayah } & \multicolumn{3}{c}{ TA 2017/2018 } & \multicolumn{3}{c}{ TA 2016/2017 } & \multicolumn{3}{c}{ TA 2015/2016 } \\
\cline { 2 - 11 } & & Jml & $\mathbf{L}$ & $\mathbf{P}$ & $\mathbf{J m l}$ & $\mathbf{L}$ & $\mathbf{P}$ & $\mathbf{J m l}$ & $\mathbf{L}$ & $\mathbf{P}$ \\
\hline 1 & Kec. Sidoarjo & 62 & 34 & 28 & 56 & 32 & 24 & 37 & 21 & 16 \\
2 & Kec. Taman & 40 & 21 & 19 & 46 & 28 & 18 & 12 & 7 & 5 \\
3 & Kec. Waru & 10 & 6 & 4 & 30 & 22 & 8 & 0 & 0 & 0 \\
4 & Kec. Krian & 42 & 20 & 22 & 33 & 15 & 18 & 0 & 0 & 0 \\
5 & Kec. Buduran & 21 & 9 & 12 & 9 & 7 & 2 & 0 & 0 & 0 \\
6 & Kec. Gedangan & 64 & 38 & 26 & 47 & 25 & 22 & 0 & 0 & 0 \\
7 & Kec. Candi & 26 & 12 & 14 & 27 & 15 & 12 & 9 & 5 & 4 \\
8 & Kec. Sukodono & 22 & 10 & 12 & 24 & 8 & 16 & 0 & 0 & 0
\end{tabular}




\begin{tabular}{rlccccccccc}
9 & Kec. Sedati & 0 & 0 & 0 & 0 & 0 & 0 & 36 & 21 & 15 \\
10 & Kec. Tulangan & 15 & 8 & 7 & 13 & 4 & 9 & 0 & 0 & 0 \\
11 & Kec. Porong & 39 & 26 & 13 & 38 & 25 & 13 & 0 & 0 & 0 \\
12 & Kec. Krembung & 11 & 9 & 2 & 4 & 4 & 0 & 12 & 9 & 3 \\
13 & Kec. Wonoayu & 14 & 8 & 6 & 13 & 9 & 4 & 0 & 0 & 0 \\
14 & Kec. Tanggulangin & 16 & 11 & 5 & 7 & 4 & 3 & 0 & 0 & 0 \\
15 & Kec. Tarik & 8 & 7 & 1 & 10 & 8 & 2 & 0 & 0 & 0 \\
16 & Kec. Balong Bendo & 0 & 0 & 0 & 0 & 0 & 0 & 0 & 0 & 0 \\
17 & Kec. Prambon & 0 & 0 & 0 & 0 & 0 & 0 & 10 & 8 & 2 \\
18 & Kec. Jabon & 0 & 0 & 0 & 0 & 0 & 0 & 0 & 0 & 0 \\
\hline Total & Total & $\mathbf{3 9 0}$ & $\mathbf{2 1 9}$ & $\mathbf{1 7 1}$ & $\mathbf{3 5 7}$ & $\mathbf{2 0 6}$ & $\mathbf{1 5 1}$ & $\mathbf{1 1 6}$ & $\mathbf{7 1}$ & $\mathbf{4 5}$ \\
\hline
\end{tabular}

Tabel 1. Data Peserta Didik SMALB Tunarungu Kabupaten Sidoarjo

Sumber: DAPODIKDASMEN 2017

Pada sekolah mitra dalam hal ini SLB Putra Mandiri menggunakan kurikulum yang mengandalkan vokasi sebagai unggulan. Siswa dalam lima hari aktif sekolah per minggu $70 \%$ nya adalah keterampilan vokasi seperti contoh membuat keset, tatarias, membuat kerajinan menggunakan bahan daur ulang, mengelas, perbengkelan, dsb. Akan tetapi amat disayangkan ketika siswa berkebutuhan khusus telah memiliki keterampilan, namun tidak memahami tindak lanjut atas apa yang telah mereka miliki tersebut. Sebagai contoh siswa telah mampu mengusai cara membuat keset, kemudian mereka tidak mengerti cara memasarkan produk mereka. Kemudian untuk tata rias saat ini banyak sekali teknik tata rias yang terus berkembang dari waktu ke waktu. Combination between RBV and Capability theory provide a clear direction in this framework as transform resources into capability will create a unique resources that hardly to imitate by others firms (Mat \& Razak, 2011; Prange \& Verdier, 2011; Teece, 2012). Oleh karena itu sesuai dengan definisi dari capability learner atau kapabilitas pebelajar dimana mereka tidak hanya memiliki satu kemampuan namun beberapa kemampuan guna mendukung satu skill yang telah dimiliki dengan baik. Dengan demikian perlu adanya sebuah solusi dimana siswa berkebutuhan khusus di SLB Putra Mandiri mampu meningkatkan capability learner mereka melalui pelatihan dalam mengkases open access system. Dengan berbagai fitur gratis dan lengkap yang ditawarkan oleh open access ditambah dengan mudahnya cara penggunannya maka dapat diyakini bahwa pelatihan ini akan sesuai dengan tujuan yaitu meningkatnya kapabilitas siswa berkebutuhan khusus.

Masalah Umum, berdasarkan uraian latar belakang pada pendahuluan dapat digaris bawahi bahwa masalah yang mendasar yang perlu segera diatasi adalah meningkatkan capability learner siswa berkebutuhan khusus di SLB Putra Mandiri. Faktor yang mendasari diambilnya masalah umum tersebut dikarenakan kajian data tabel jumlah siswa berkebutuhan khusus di Kabupaten sidoarjo yang notabanenya memiliki jumlah yang cukup signifikan, sedangkan keterampilan mereka pada pasca sekolah sangat minim hal itu berdasarkan kajian penelitan dan pengabdian pada tahun sebelumnya dengan judul "Orientasi kerja siswa disabilitas di Kabupaten Sidoarjo" pada tahun 2018, sehingga perlu adanya respon terhadap permalasahan tersebut agar dapat segera tertangani.

Masalah Khusus, secara khusus, garis besar masalah tersebut dapat dijabarkan sebagai berikut: (1) Siswa berkebutuhan khusus di SLB Putra Mandiri belum memahami kapabilitas pebelajar.; (2) Siswa berkebutuhan khusus di SLB Putra Mandiri memerlukan sebuah instrument untuk meningkatkan capability learner mereka.

\section{METODE}

Target peserta sebagai khalayak sasaran antara yang strategis untuk dilibatkan dalam kegiatan pemberdayaan ini ada 25 orang siswa SLB Putra Mandiri di wilayah Kabupaten Sidoarjo (terlampir), yang terdiri dari: (1) Siswa berkebutuhan khusus dengan hambatan pendengaran (tunarungu) mulai dari jenjang SMP dan SMA dengan tingkatan kelas 1, 2, dan 3 dengan Jumlah 15 (lima belas) orang; (2) Siswa berkebutuhan khusus dengan hambatan fisik dan motorik (tunadaksa) 
mulai dari jenjang SMP dan SMA dengan tingkatan kelas 1, 2, dan 3 dengan tingkatan kelas 1, 2, dan 3 dengan jumlah 5 (lima) orang; (3) Siswa berkebutuhan khusus dengan hambatan intelektual (tunagrahita) mulai dari jenjang SMP dan SMA dengan tingkatan kelas 1, 2, dan 3 dengan Jumlah 10 (lima belas) orang.

Target umum yang diharapkan pada ada akhir kegiatan pemberdayaan diharapkan siswa SLB Putra Mandiri Kabupaten Sidoarjo memiliki capability learner sehingga mampu mengembangkan kapabilitas untuk mendukung kemampuan yang sudah dimiliki sebelumnya. Secara detail dijabarkan sebagai berikut: (1) Peserta mampu memahami kapabilitas dalam diri; (2) Peserta mampu memahami materi pelatihan terkait dengan kapabilitas diri; (3) Peserta mampu mengimplemntasikan seluruh materi praktek yang telah dilatihkan

Target khusus diharapkan pada akhir kegiatan pelatihan diharapkan: (1) Siswa berkebutuhan khusus di SLB Putra Mandiri memahami kapabilitas mereka masing masing; (2) Siswa berkebutuhan khusus di SLB Putra Mandiri mampu mengimplemntasikan open access system dengan baik (3) Siswa berkebutuhan khusus di SLB Putra Mandiri memiliki peningkatan pada kapabilitasnya.

Tahapan kegiatan yang akan dilakukan untuk mencapai tujuan dari kegiatan pengabdian kepada masyarakat ini adalah sebagai berikut: (1) Satgas menjalin kerjasama dengan partner mitra di luar UM dalam hal ini yang menjadi mitra adalah Sekolah Luar Biasa Putra Mandiri Kabupaten Sidoarjo yang berkaitan dengan lokasi dan para peserta pengabdian; (2) Satgas mempelajari tentang capability Learner khususnya untuk anak berkebutuhan khusus; (3) Satgas bersama mitra memberikan paparan materi tentang Capability Learner; (4) Satgas bersama mitra memberikan paparan materi tentang Open Access System; (5) Peserta mencoba mengaplikasikan Open Access System secara mandiri; (6) Satgas bersama mitra melakukan evaluasi pada para peserta pemberdayaan yang nantinya akan menghasilkan rekomendasi pada seluruh peserta.

Pelaksanaan pelatihan yang dilakukan dengan metode yang digunakan dalam pelatihan meliputi: (1) Ceramah dan Tanya jawab untuk menyampaikan wawasan dunia kerja dan tentang persiapan masuk dalam dunia kerja sebagai sarana membentuk etos kerja atau mental kerja dalam dunia kerja; (2) Praktek; (3) Diskusi untuk melakukan evaluasi rekomendasi pada seluruh peserta pemberdayaan.

Alasan penggunaan metode tersebut dikarenakan pemberdayaan ini difokuskan pada konsep pemahaman peserta terhadap materi dan ditambah dengan pengalaman praktis yang didapatkan melalui praktek atau unjuk kerja setelah diberikan pemahaman yang mendalam. Kegiatan pemberdayaan ini direncanakan dilaksanakan selama 2 Hari. Kegiatan hari pertama meliputi materi terkait tentang Pengenalan Potensi diri pada siswa dan Konsep Capability Learner. Kedua materi tersebut dimaksudkan untuk siswa mengenali potensi dan passion yang ada pada dirinya yang kemudian mereka mampu meningkatkan dan mengembangkan kapabilitasnya dengan tepat. Pada hari kedua adalah materi tentang Open Access System yang meliputi fitur, fungsi, dan manfaat program tersebut guna menunjang siswa dalam mengembangkan potensi dirinya. Setelah siswa diberikan materi terkait dengan fitur dan fungsi dari Open Access System yang dalam hal ini berbasis website, kemudian mereka diajarkan secara langsung (Praktek) dalam mengoperasikannya menggunakan 3 (tiga) macam Perangkat yaitu, Komputer, Laptop, dan Smartphone, Hal ini dimaksudkan untuk memberikan wawasan bahwa Open Access System ini bersifat mobile dan dapat diakses melalui tiga perangkat tersebut. Adapun rangkaian rencana kegiatan Pemberdayaan dapat dilihat pada tabel 2 .

\begin{tabular}{|c|c|c|c|c|}
\hline No. & Pemateri & Materi & Hari/Sesi & Keterangan \\
\hline 1 & $\begin{array}{l}\text { Dwi Wahyuni S.Pd / Umi } \\
\text { Safiul Ummah, M.Pd }\end{array}$ & Pengenalan Potensi Diri & $1 / 1$ & $\begin{array}{l}\text { Mahasiswa Membantu } \\
\text { Sebagai Penerjemah } \\
\text { Bahasa Isyarat } \\
\text { Mahasiswa Membantu }\end{array}$ \\
\hline 2 & Ence Surahman, M.Pd & Capability Learner & $1 / 2$ & $\begin{array}{l}\text { Sebagai Penerjemah } \\
\text { Bahasa Isyarat }\end{array}$ \\
\hline 3 & $\begin{array}{l}\text { Rizqi Fajar Pradipta, } \\
\text { M.Pd }\end{array}$ & Open Access System & $2 / 1$ & $\begin{array}{l}\text { Mahasiswa Membantu } \\
\text { Sebagai Penerjemah } \\
\text { Bahasa Isyarat }\end{array}$ \\
\hline
\end{tabular}


Ence Surahman, M.Pd / Rizqi Fajar Pradipta, M.Pd
Praktek Penggunaan Open Access System
Mahasiswa Membantu Sebagai Penerjemah Bahasa Isyarat dan Mendampingi Siswa

\section{Tabel 2. Rencana Kegiatan}

Sumber: Dokumen Pribadi

Evaluasi Pelatihan, kegiatan pengabdian kepada masyarakat ini dilakukan terhadap proses pelatihan dan hasil pelatihan. Evaluasi proses pelatihan meliputi: (a) Keaktifan peserta, sebagai indikator dan tolok ukurnya yaitu dilihat dari kehadiran dan keterlibatan mahasiswa dalam pelatihan; (b) Kerjasama, sebagai indikator dan tolok ukurnya yaitu Inisiatif dalam memimpin, mengorganisir peserta lain, memunculkan ide kreatif diikuti peserta lain, dan oleransi dan menghargai ide peserta lain; (c) Keterampilan, sebagai indikator dan tolak ukurnya yaitu : kecekatan, ketepatan, ketelitian dalam menyelesaikan setiap pekerjaan dan efisiensi waktu dalam menyelesaikan setiap pekerjaan

Evaluasi hasil pelatihan meliputi: (a) Penguasaan teori materi pelatihan, sebagai indikator dan tolok ukurnya yaitu penerapan teori dalam praktek, (b) Penguasaan praktek Open Access System, sebagai indikator dan tolak ukurnya yaitu peserta memenuhi kriteria penilaian tidak kurang dari $80 \%$ dari 4 aspek kriteria penilaian keterampilan penggunaan

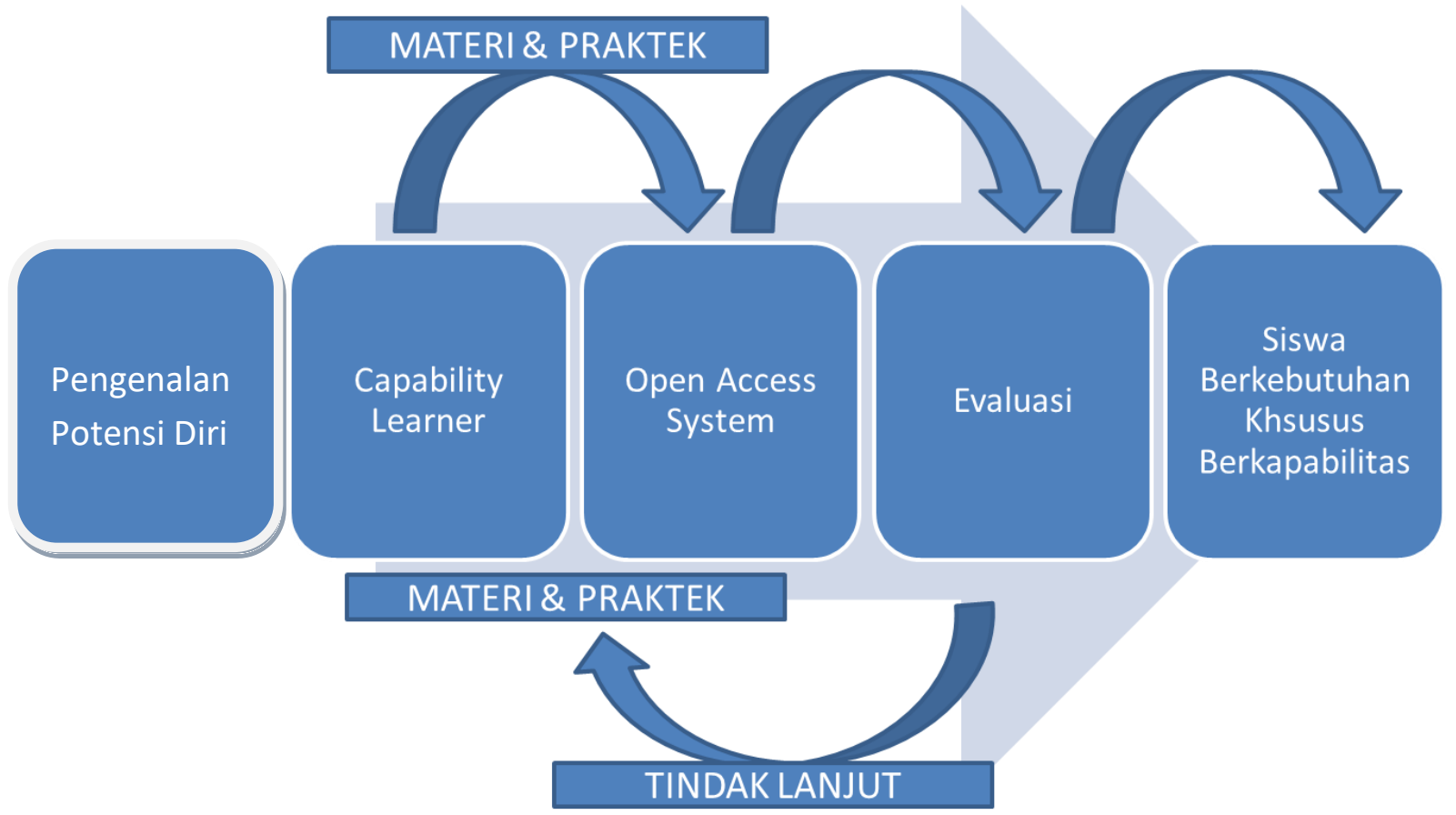

Gambar 1. Alur Kegiatan Pengabdian Masyarakat Sumber: Dokumen Pribadi

\section{HASIL DAN PEMBAHASAN}

Pada akhir kegiatan Pemberdayaan Siswa Berkebutuhan Khusus Dalam Mengakses Open Access System Untuk Meningkatkan Capability Learner, Peserta telah memiliki pengetahuan dan pemahaman tentang pengenalan potensi diri dan open access system sehingga mampu menggunakan atau menerapkan seluruh program pelatihan dalam kegiatan atau aktifitas mereka yang berkaitan dengan kapabilitas mereka masing-masing sesuai dengan potensi yang mereka miliki. Pada akhir kegiatan sosialisasi peserta mendapatkan, antara lain; (1) Meningkatnya pemahaman terhadap potensi atau ketertarikan bidang sesuai dengan kemampuan yang ada pada diri siswa berkebutuhan khusus tunarungu dan daksa; (2) Memahami serta mampu menggunakan dengan baik open access system sesuai dengan peningkatan potensi kapabilitas siswa sesuai dengan bidang keahlian yang ada dalam diri siswa berkebutuhan khusus. 
Luaran yang telah dilaksanakan dari program pengabdian kepada masyarakat ini sesuai dengan resentra penelitian dan pengabdian masyarakat Fakultas IImu Pendidikan Universitas Negeri Malang yaitu pengembangan Lingkungan Sekolah. Luaran dari hasil kegaiatan pengabdian masyarakat ini terdiri dari dua luaran, yaitu luaran wajib dan luaran tambahan. (1) Luaran wajib kegiatan sosialisasi adalah sebagai berikut: artikel ilmiah yang di publikasikan melalui jurnal ber ISSN yang akan menjadi tujuan TIM kami adalah Jurnal Praksis dan Dedikasi Sosial yang di terbitkan Oleh Fakultas IImu Sosial Universitas Negeri Malang di Malang. Kami memilih jurnal Pengabdian Kepada Masyarakat karena telah ber ISSN dengan nomor registered number E-ISSN 2655-2469 dan Scope jurnal sudah sesuai dan mengunggah laporan kegiatan pada laman berita online sehingga dapat di akses secara penuh sebagai bahan rujukan sesuai dengan visi UM sebagai perguruan tinggi rujukan.

Luaran tambahan kegiatan sosialisasi adalah sebagai berikut: (1) Mengunggah artikel pada Publikasi Internasional terakreditasi; (2) Membangun layanan konsultasi apabila ada permalasahan dikemudian hari sebagai dampak dari kegiatan pelatihan.

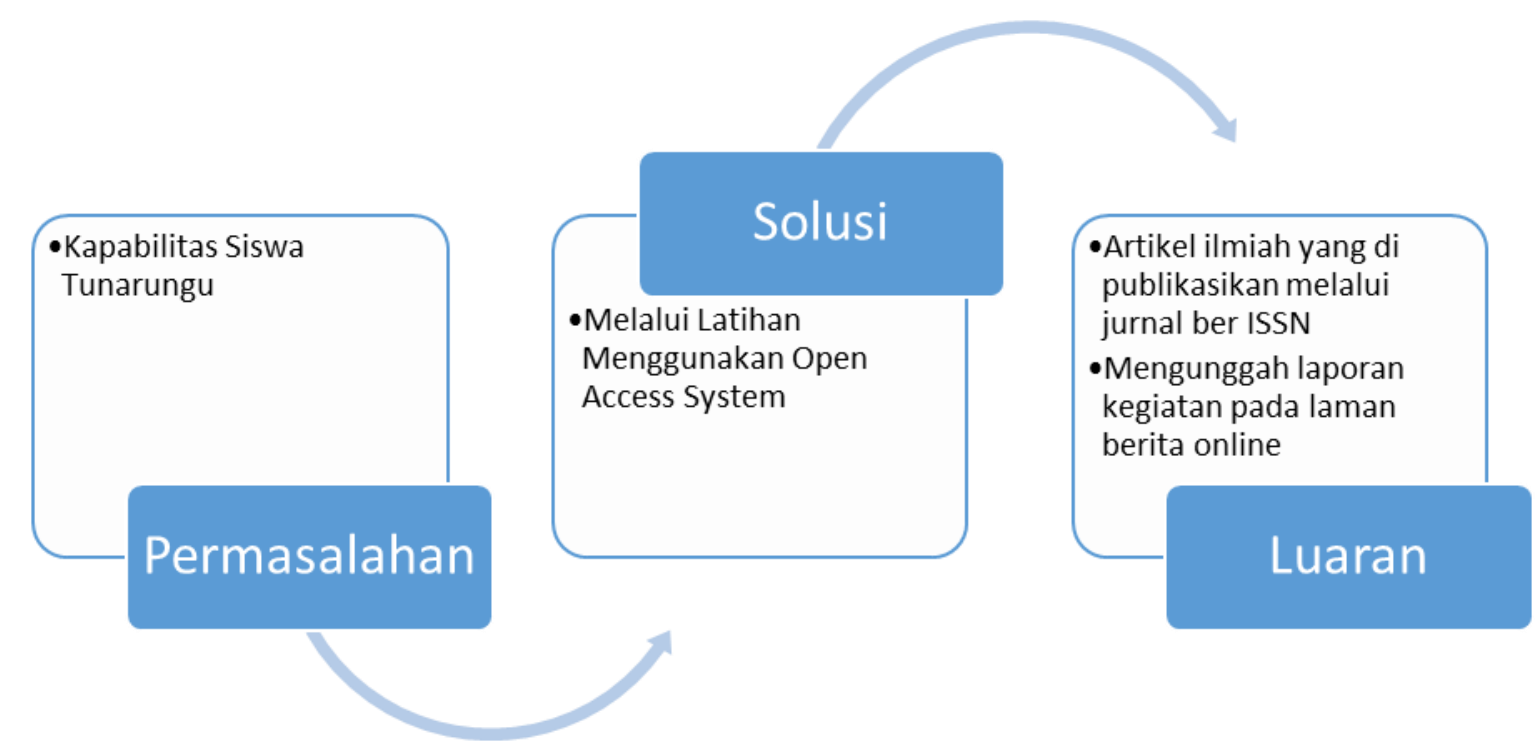

Gambar 2. Mind Map Kegiatan

Sumber: Dokumen Pribadi

\section{KESIMPULAN}

Berdasarkan hasil kegiatan pemberdayaan siswa berkebutuhan khusus yang dilaksanakan di Sekolah Luar Biasa Kabupaten Sidoarjo dapat disimpulkan bahwa dalam meningkatkan kapabilitas siswa berkebutuhan khusus dapat menggunakan sistem pelatihan atau pemberdayaan dengan metode pelaksanaan yang telah digunakan pada kegiatan ini. Pada dasarnya metode pelaksanaan yang dugunakan sudah sesuai karena dalam penentuannya menggunakan pendekatan dan kajian mendalam dikarenakan karakteristik siswa berkebutuhan khusus sehingga memerlukan upaya adaptasi dalam mentransfer konsep ilmu dan praktek.

\section{DAFTAR PUSTAKA}

Baker, W. E., \& Sinkula, J. M. 2005. Environmental marketing strategy and firm performance: Effects on new product performance and market share. Journal of the Academy of Marketing Science, 33(4), 461-475.

Mat, A., \& Razak, R. C. 2011. The influence of organizational learning capability on success of technological innovation (product) implementation with moderating effect of knowledge complexity. International Journal of Business and Social Science, 2(17).

Prange, C., \& Verdier, S. 2011. Dynamic capabilities, internationalization processes and performance. Journal of World Business, 46(1), 126-133.

Prasetyo, H., \& Sutopo, W. 2018. Industri 4.0: Telaah Klasifikasi aspek dan arah perkembangan riset. J@ Ti Undip: Jurnal Teknik Industri, 13(1), 17-26. 
Suwardana, H. 2018. Revolusi Industri 4. 0 Berbasis Revolusi Mental. JATI UNIK: Jurnal IImiah Teknik Dan Manajemen Industri, 1(2), 102-110.

Teece, D. J. 2012. Dynamic capabilities: Routines versus entrepreneurial action. Journal of Management Studies, 49(8), 1395-1401.

Tjandrawinata, R. R. 2016. Industri 4.0: Revolusi industri abad ini dan pengaruhnya pada bidang kesehatan dan bioteknologi. Jurnal Medicinus, 29(1).

Untara, W. 2014. Kamus Bahasa Indonesia: Edisi Revisi. IndonesiaTera. 